\title{
Retraction note: Neuropathological microscopic features of abortions induced by Bunyavirus/or Flavivirus infections
}

\author{
Javad Javanbakht ${ }^{1}$, Seyed Hossein Mardjanmehr ${ }^{1 *}$, Abbas Tavasoly ${ }^{1}$ and Mohammad Hossein Nazemshirazi ${ }^{2}$
}

\section{Retraction}

The Editor-in-Chief and Publisher have retracted this article [1] because the scientific integrity of the content cannot be guaranteed. An investigation by the Publisher found it to be one of a group of articles we have identified as showing evidence suggestive of attempts to subvert the peer review and publication system to inappropriately obtain or allocate authorship. This article showed evidence of plagiarism (most notably from the articles cited [2-7]) and peer review and authorship manipulation.

\footnotetext{
Author details

'Department of Pathology, Faculty of Veterinary Medicine, Tehran University, Tehran, Iran. ${ }^{2}$ Department of Molecular Biology, Central Veterinary Laboratory of I.V.O, Tehran, Tehran, Iran.
}

Received: 17 October 2016 Accepted: 19 October 2016

Published online: 02 November 2016

\section{References}

1. Javanbakht J, Mardjanmehr SH, Tavasoly A, Nazemshirazi MH. Neuropathological microscopic features of abortions induced by Bunyavirus/or Flavivirus infections. Diagn Pathol. 2014;9:223.

2. Kessell AE, Finnie JW, Windsor PA. Neurological diseases of ruminant livestock in Australia. IV: viral infections. Aust Vet J. 2011;89(9):331-7.

3. Ali H, Ali AA, Atta MS, Cepica A. Common, emerging, vector-borne and infrequent abortogenic virus infections of cattle. Transbound Emerg Dis. 2012;59(1):11-25.

4. Herder V, Hansmann F, Wohlsein P, Peters M, Varela M, Palmarini M, Baumgärtner W. Immunophenotyping of inflammatory cells associated with Schmallenberg virus infection of the central nervous system of ruminants. PLoS One. 2013;8(5):e62939.

5. Chung S-I, Livingston Jr CW, Edwards JF, Crandell RW, Shope RE, Shelton $\mathrm{MJ}$, Collisson EW. Evidence that cache valley virus induces congenital malformations in sheep. Vet Microbiol. 1990;21(4):297-307.

6. Herder V, Wohlsein P, Peters M, Hansmann F, Baumgärtner W. Salient lesions in domestic ruminants infected with the emerging so-called Schmallenberg virus in Germany. Vet Pathol. 2012;49(4):588-91.

7. Gyure KA. Neuropathologic diagnosis of central nervous system viral diseases. In: Hayasaka D, editor. Pathogenesis of Encephalitis. Rijeka: InTech; 2011. p. 19-41. doi:10.5772/20361.

\footnotetext{
* Correspondence: hmehr@ut.ac.ir

'Department of Pathology, Faculty of Veterinary Medicine, Tehran University, Tehran, Iran
} 